\title{
Long-term variation in an occurrence of $R$ habditis orbitalis parasitic larvae (Nematoda, Rhabditidae) in the eyes of montane rodents
}

\author{
M. KOCIANOVÁ-ADAMCOVÁ ${ }^{1}$, M. ŠPAKULOVÁ $*^{2}$, E. KOCIANOVÁ ${ }^{3}$
}

\begin{abstract}
${ }^{1}$ Department of Biology, Faculty of Natural Sciences, Matej Bel University, Tajovského 40, 97401 Banská Bystrica, Slovakia; E-mail: adamcova@fpv.umb.sk; ${ }^{2}$ Parasitological Institute Slovak Academy of Sciences, Hlinkova 3, 040 01 Košice, Slovakia; E-mail: spakulma@saske.sk; ${ }^{3}$ Institute of Virology, Slovak Academy of Sciences, Dúbravská cesta 9, 84245 Bratislava, Slovakia; E-mail: virukoc@savba.sk
\end{abstract}

\begin{abstract}
Summary
During a long-term survey $(1999$ - 2005) of parasitic larvae of nidicolous nematode Rhabditis orbitalis Sudhaus et Schulte, 1986 in the West Tatra Mts, the nematodes were detected in the eye orbits of snow voles Chionomys nivalis in 1999, 2004 and 2005. In the last year, R. orbitalis was detected also in another vole species Clethrionomys glareolus and Microtus tatricus both in previously studied site and in the Low Tatra Mts, however, it has never appeared at other rodent species. For the first time, an irregular occurrence of the $R$. orbitalis parasitic larvae has been ascertained in natural conditions of the Slovak mountains. The eye nematodes occurred only during autumn or cold and rather wet summer months, when density of the preferred host $C h$. nivalis was relatively low. A hypothesis has been put forward that an occasional appearance of parasitic eye larvae in the life cycle of bacteriophagous $R$. orbitalis represents a strategy for surviving periods of a scarcity of bacterial food, which could be influenced by a combination of weather conditions, density of host rodents and seasonal abundance of $R$. orbitalis in rodent nests.
\end{abstract}

Key words: Rhabditis orbitalis; Nematoda; Rodentia; Tatra Mountains

\section{Introduction}

A microbotrophic nematode Rhabditis orbitalis Sudhaus et Schulte, 1986 lives in nests of wide range of small rodents of the families Arvicollidae, Muridae and Gliridae in Holarcic (Casanova et al., 1996; Sainsbury et al., 1996; Yensen et al., 1996; Ito \& Itagaki, 2003). It was learned experimentally (Schulte, 1989), that its two-stage larvae can develop in three ways (larval "triphenism"). They i) transform into free-living $\mathrm{L}_{3}, \mathrm{~L}_{4}$ and adults, or ii) form "dauer" $\mathrm{L}_{3}$ stage which retain the cuticle of the second stage and arrest their development until suitable conditions will be attained, or iii) develop into infective $\mathrm{L}_{3}$ larvae. The parasitic larvae live in the orbit and conjunctival sacs of rodents, feed on lachrymal secretions, increase in size, and after minimum of $3-19$ days leave the orbit and enter the nest or runways of the host (Sudhaus et al., 1987; Schulte, 1989; Hugot \& Quentin, 2000). No sign of inflammation of host eyes has been referred till now even during intense infections up to 100 larvae (Schulte, 1989; Casanova et al., 1996). According to Schulte (1989), the life cycle of $R$. orbitalis carries on in rodent nests continuously.

The present paper reports on the occurrence of $R$. orbitalis in three vole species that were captured and examined alive during a 7 year-study in the subalpine zone of the Roháče (West Tatra) Mountains as well as in a one-year study of the same rodents in the Low Tatra Mountains. Recent data were compared with a survey carried out in the same regions nearly three decennia ago (Baruš \& Hrabě, 1991). The present long-time study of $R$. orbitalis in natural mountain conditions has enabled us to evaluate meteorological data in the examined seasons and to assess potential impacts influencing the irregular occurrence of parasitic larval type within a life-cycle of bacteriophagous $R$. orbitalis.

\section{Materials and Methods}

In the period from 1999 to 2005, an ecological investigation of population dynamics as well as the sexual and spatial activity of small ground rodents has been performed in the region of Roháče (West Tatra Mountains, around the Lake Prvé Roháčské pleso, 1,500 - 1,600 m above see level). With respect of the rough weather conditions in mountains, three trapping series were conducted every year from June to October. Sampling followed the classical

${ }^{*}$ Corresponding author 
Capture-Marking-Recapture (CMR) method and captured rodents were surveyed for sex, weight, size, sexual activity (Kocianová et al., 2002; Žiak et al., 2004) and for a presence of larvae of nematode $R$. orbitalis in eye orbits of living animals. Since 1999, 7 rodent species were captured, namely Chionomys nivalis (Martins, 1842), Clethrionomys glareolus (Schreber, 1780), Microtus tatricus Kratochvíl, 1952, M. agrestis (L., 1761), Apodemus flavicollis (Melchior, 1834), Sicista betulina (Pallas, 1779) and Muscardinus avellanarius (L., 1758). A single infected individual of Ch. nivalis, captured in 1999, was dissected and eye nematodes were isolated from conjunctival sacs. They were then counted, fixed in $70 \%$ ethanol, cleared in glycerine and identified according to Schulte (1989) and Baruš and Hrabě (1991).

In summer 2005, an additional alpine locality was monitored, namely the alpine zone of the Low Tatra Mountains (Král'ova hol'a peak, 1,948 m above sea level). During three-month trapping series (June, July, August 2005), 5 rodent species (Ch. nivalis, C. glareolus, M. tatricus, $M$. agrestis and $A$. flavicollis) were captured.

The research was allowed by the permission of the Ministry of Environment of the Slovak Republic no. 1021/0437/ $1999-4,1$ pil (1999 - 2002), 2141/556/03 - 5,1 pil (2003 $-2005)$.

\section{Results}

In Roháče Mts, the eye nematodes were detected in orbits of a single specimen of snow vole $C h$. nivalis in 1999 and in representatives of Ch. nivalis, C. glareolus and M. tatricus in 2004 and 2005 (Tab. 1). In total, 937 living individuals of these species were investigated (406 females and 531 males).

From conjuctival sacs of a single $C h$. nivalis dissected in 1999, 15 nematode larvae were isolated, morphologically characterised and identified as parasitic third-stage larvae of $R$. orbitalis. The caudal region of larvae showed two discoidal phasmids and a mucro on a tip of the tail. The fully developed individuals $(\mathrm{n}=11)$ were up to $0.92 \mathrm{~mm}$ long. During the subsequent search for the eye larvae, rodents were examined alive and the number of the larvae (values of intesity of infection) were not evaluated.

A regular search for the eye larvae of $R$. orbitalis was performed during the four subsequent years without any result. In August 2004, 2 snow voles out of 31 captured were positive for $R$. orbitalis, and in the end of September/beginning of October, 3 positive snow voles were found out of 36 investigated. Similarly, we detected 2 positive $C h$. nivalis out of 28 inspected in August 2005. In September/ October, eye larvae of $R$. orbitalis were found in high prevalence in 3 vole species Ch. nivalis, C. glareolus and $M$. tatricus (prevalence values 57.9, 17.8 and $37.5 \%$, respectively, Tab. 1).

In August 2005, parasitic larvae of $R$. orbitalis were found in the same rodent species also in another alpine site, the top of Král'ova hol'a peak in the Low Tatra Mts. The prevalence was rather high in all 3 host species, namely in the snow vole $(66.7 \%)$, bank vole $(42.8 \%)$ and Tatra vole $(33.3 \%)$. However, numbers of investigated animals were relatively low (Tab. 2).

As the trapping series in Roháče Mts were performed repeatedly in the identical sites and the trapped rodents were marked, some individuals were re-captured. In 2005, we detected 4 snow voles being free of $R$. orbitalis in June and July and infected in September/October. Two another specimens of $C h$. nivalis infected in August were infected again in September/October. Concerning a comparison of infection rate in rodent females and males, no remarkable differences were found $\left(\chi^{2}\right.$ tests $\left.>0.05\right)$. There were no differrences in both weight and physical condition between infected and uninfected rodents.

Table 1. Occurrence of eye $\mathrm{L}_{3}$ larvae of Rhabditis orbitalis in rodents captured in Roháče Mountains $(1,500-1,600 \mathrm{~m})$

\begin{tabular}{|c|c|c|c|c|c|c|c|c|c|c|}
\hline \multirow{2}{*}{ Period of collection } & & \multicolumn{3}{|c|}{ Chionomys nivalis } & \multicolumn{3}{|c|}{ Clethrionomys glareolus } & \multicolumn{3}{|c|}{ Microtus tatricus } \\
\hline & & $\begin{array}{l}\text { No. of } \\
\text { examined } \\
\text { F/M* }^{*}\end{array}$ & $\begin{array}{l}\text { No. of } \\
\text { infected } \\
\text { F/M }\end{array}$ & $\begin{array}{c}\text { Prevalence } \\
(\%)\end{array}$ & $\begin{array}{l}\text { No. of } \\
\text { examined } \\
\text { F/M }\end{array}$ & $\begin{array}{l}\text { No. of } \\
\text { infected } \\
\text { F/M }\end{array}$ & $\begin{array}{c}\text { Prevalence } \\
(\%)\end{array}$ & $\begin{array}{l}\text { No. of } \\
\text { examined } \\
\text { F/M }\end{array}$ & $\begin{array}{l}\text { No. of } \\
\text { infected } \\
\text { F/M }\end{array}$ & $\begin{array}{c}\text { Prevalence } \\
(\%)\end{array}$ \\
\hline June - August & 1999 & $23 / 20$ & 0 & 0 & $2 / 2$ & 0 & 0 & $4 / 4$ & 0 & 0 \\
\hline \multirow[t]{5}{*}{ September - October } & 1999 & $15 / 19$ & $0 / 1$ & 2.9 & $1 / 1$ & 0 & 0 & $4 / 2$ & 0 & 0 \\
\hline & 2000 & $38 / 57$ & 0 & 0 & $4 / 7$ & 0 & 0 & $7 / 7$ & 0 & 0 \\
\hline & 2001 & $35 / 47$ & 0 & 0 & $4 / 15$ & 0 & 0 & $5 / 5$ & 0 & 0 \\
\hline & 2002 & $50 / 40$ & 0 & 0 & $21 / 23$ & 0 & 0 & $4 / 2$ & 0 & 0 \\
\hline & 2003 & $46 / 48$ & 0 & 0 & $0 / 0$ & 0 & 0 & $4 / 3$ & 0 & 0 \\
\hline June - July & 2004 & $12 / 9$ & 0 & 0 & $5 / 12$ & 0 & 0 & $3 / 3$ & 0 & 0 \\
\hline August & 2004 & $12 / 19$ & $0 / 2$ & 6.5 & $18 / 24$ & 0 & 0 & $9 / 0$ & 0 & 0 \\
\hline September - October & 2004 & $9 / 27$ & $1 / 2$ & 8.3 & $18 / 37$ & 0 & 0 & $4 / 5$ & 0 & 0 \\
\hline June - July & 2005 & $5 / 6$ & 0 & 0 & $2 / 6$ & 0 & 0 & $3 / 1$ & 0 & 0 \\
\hline August & 2005 & $11 / 17$ & $1 / 1$ & 7.1 & $3 / 11$ & 0 & 0 & $2 / 1$ & 0 & 0 \\
\hline September - October & 2005 & $14 / 24$ & $7 / 15$ & 57.9 & $6 / 22$ & $1 / 4$ & 17.8 & $3 / 5$ & $1 / 2$ & 37.5 \\
\hline Total & & $270 / 333$ & $9 / 21$ & 5.0 & $84 / 160$ & $1 / 4$ & 2.0 & $52 / 38$ & $1 / 2$ & 3.3 \\
\hline
\end{tabular}

* F-female; $\mathrm{M}$ - male 
Table 2. Occurrence of eye $\mathrm{L}_{3}$ larvae of Rhabditis orbitalis in rodents captured in The Low Tatra Mountains (1,948 m)

\begin{tabular}{|c|c|c|c|c|c|c|c|c|c|c|}
\hline \multirow{2}{*}{\multicolumn{2}{|c|}{$\begin{array}{c}\text { Period } \\
\text { of } \\
\text { collection }\end{array}$}} & \multicolumn{3}{|c|}{ Chionomys nivalis } & \multicolumn{3}{|c|}{ Clethrionomys glareolus } & \multicolumn{3}{|c|}{ Microtus tatricus } \\
\hline & & $\begin{array}{c}\text { No. of } \\
\text { examined } \\
\text { F/M* }\end{array}$ & $\begin{array}{l}\text { No. of } \\
\text { infected } \\
\text { F/M }\end{array}$ & $\begin{array}{c}\text { Prevalence } \\
(\%)\end{array}$ & $\begin{array}{c}\text { No. of } \\
\text { examined } \\
\text { F/M }\end{array}$ & $\begin{array}{l}\text { No. of } \\
\text { infected } \\
\text { F/M }\end{array}$ & $\begin{array}{c}\text { Prevalence } \\
(\%)\end{array}$ & $\begin{array}{c}\text { No. of } \\
\text { examined } \\
\text { F/M }\end{array}$ & $\begin{array}{c}\text { No. of } \\
\text { infected } \\
\text { F/M }\end{array}$ & $\begin{array}{c}\text { Prevalence } \\
(\%)\end{array}$ \\
\hline June - July & 2005 & $1 / 2$ & 0 & 0 & $14 / 12$ & 0 & 0 & $2 / 1$ & 0 & 0 \\
\hline August & 2005 & $1 / 2$ & $1 / 1$ & 66.7 & $9 / 5$ & $3 / 3$ & 42.8 & $1 / 2$ & $0 / 1$ & 33.3 \\
\hline Total & & $2 / 4$ & $1 / 1$ & 33.3 & $23 / 17$ & $3 / 3$ & 15.0 & $3 / 3$ & $0 / 1$ & 16.7 \\
\hline
\end{tabular}

* $\mathrm{F}$ - female; $\mathrm{M}$ - male

\section{Discussion}

A complex of four sibling nematode species of the genus Rhabditis Dujardin, 1845, namely $R$. strongyloides (Schneider, 1960), $R$. orbitalis, $R$. nidicolis Sudhaus et Schulte, 1986 and $R$. cutanea Sudhaus, Schulte et Hominick, 1987, occurring in the nesting material of rodents or some birds can either develop as free-living nidicolous nematodes or their life cycle involves parasitic third-stage larvae, localised in diverse host sites like skin (hair follicles) or eye orbits and conjunctival sacs (for review see Sudhaus et al., 1987). Out of them, $R$. orbitalis was noticed relatively frequently. Its third-stage parasitic larvae were detected within eye orbits and lachrymal sacs of various rodents in Holarctic when moving intensively in the eye orbit, or during overall surveys of helminth fauna of small ground mammals (Yagi et al., 1983; Sudhaus \& Asakawa, 1991; Tenora \& Baruš, 1991; Casanova et al., 1996; Yensen et al., 1996; Ito \& Itagaki, 2003). Several other papers were focused directly on the research of $R$. orbitalis occurrence (Cross \& Santana, 1974; Prokopič et al., 1974; Baruš \& Hrabě, 1991; Schulte \& Poinar, 1991; Sainsbury et al., 1996). Nevertheless, none of the previous studies involved yearly repeated research of a single locality.

During the present 7-year-study, we managed to identify the larvae occurring in the rodent eyes only once, when they were isolated from a single dissected $C h$. nivalis. Thereafter, the further cases of eye infections in live rodents were regarded as $R$. orbitalis because of an apparent similarity in visual aspects and behaviour. Moreover, no other eye nematode parasite had been found in European rodents till now. Our examinations have reliably detected a presence of several larvae and sometimes only the single larva was noticed, indeed. However, we concede that a single individual may have been overlooked as it can hide rapidly to the conjunctival sac. The exact data on infection rate can only be gained using a directed necropsy like those in the survey made by Baruš and Hrabě (1991) in the territory of former Czechoslovakia. The authors dissected 579 rodents of 6 species, namely Ch. nivalis, C. glareolus, M. tatricus, M. agrestis, Microtus arvalis (Pallas, 1778) and $M$. subterraneus (de Selys-Longchamps, 1836), captured in 7 localities situated from 500 to $1,500 \mathrm{~m}$ above sea level. All the vole species were infected with $R$. orbitalis larvae in some of the sites. The authors concluded that the prevalence of eye larvae decreased with increasing sea level being up to $80 \%$ in sites under $750 \mathrm{~m}$ above sea level and up to $24 \%$ in mountain localities from 750 to $1,500 \mathrm{~m}$. Their results from Roháče Mts $(1,500 \mathrm{~m})$ fit well with the present results. In 1977, the only captured vole species was Ch. nivalis which was infected with eye larvae in prevalence of $24.2 \%$ from the end of July to August. Nearly three decades later, we proved the frequent occurrence of Ch. nivalis in this region and the living snow voles were infected from 2.9 to $57.9 \%$. Baruš and Hrabě (1991) investigated also rodents from the Low Tatra Mountains, however, their survey took place in much lower altitude ( $750 \mathrm{~m}$ above sea level versus $1,948 \mathrm{~m}$ in our study). Therefore, the results are hardly comparable. In 1979, quite high prevalence rates $(47.6-81.3 \%)$ were found in $M$. subterraneus, M. arvalis and M. agrestis) during October/ November while we detected 33.3 - $66.7 \%$ prevalence in M. tatricus, C. glareolus and Ch. nivalis and no infection in M. agrestis in August 2005. Nevertheless, the longtermed occurrence of $R$. orbitalis in the regions has been proved clearly.

The peculiar life cycle of $R$. orbitalis was investigated experimentally by Schulte (1989) as mentioned above. In fact, behavioural particulars and intimate relationships between rodents and their nest associate nematode have not been revealed. Larval parasitism of $R$. orbitalis has been considered as obligatory phenomenon because parasitic larvae regularly die when they do not find a rodent host within 6 weeks (Schulte, 1989). The present study indicates that the life cycle of $R$. orbitalis could be completed without an appearance of this larval eye type even during several years, or that the occurrence of eye larvae might be negligible.

Several hypotheses have been proposed by Schulte (1989) and Baruš and Hrabě (1991) that the occurrence of parasitic eye larvae might be connected with i) specific behaviour of arvicolid rodents, which every few hours return to their nests, ii) changes in rodent population density, and iii) microclimate characteristics within rodent nests influenceing an amount and quality of bacterial food.

Firstly, we can agree that the eye larvae occur predominantly in vole species. In mountain areas of Carpathian Mts, Ch. nivalis is apparently the preferred hosts of this 
nematode while the other rodent representatives $A$. flavicollis, $S$. betulina and $M$. avellanarius were not infected in the same sites. The similar results were published by $\mathrm{Ca}$ sanova et al. (1996) from the Pyrenees Mountains where Ch. nivalis was found out a single infected species out of four rodent representatives.

Secondly, annual densities of Ch. nivalis in the Roháče Mts could be assessed according to the number of captured individuals because the same capturing sites were used in all years. In spite of the fact that densities of this non-hibernating vole used to be very low (Luque-Larena et al., 2002; Martínková \& Dudich, 2003), we were able to inspect from 77 to 95 individuals per a year. The highest numbers of snow voles were seen from 2000 to 2003 (95, 82, 90 and 94, respectively), when surprisingly, eye larvae were not detected (see Tab. 1).

The third hypothesis concerned the microclimate of rodent nests. It is likely that a temperature and humidity inside the nests of Ch. nivalis in the rocky area of Roháče Mts are quite stable, because nests are situated rather deep (even more than $2 \mathrm{~m}$ ) under the ground. We tried to measure the temperature inside a nest and it was about $2^{\circ} \mathrm{C}$ during an August day. However, a short-therm rhythm of snow vole activity indicates that e.g. wet animals returning to nest can increase the humidity inside it during the rainy days. Similarly, we can speculate that rodent recurrences into the nest could differ in wet and sunny days, and in cold and warm weather. Therefore, the behaviour and life cycle of the nest nematodes can not only be influenced by the nest microclimate but also by the outside climate.

Therefore, rainfall and temperature averages were analysed during all collecting series and months with and without occurrence of eye larvae were compared (August-October of 1999, 2004 and 2005 versus 2000 - 2004). Month averages of air temperature and rainfall from the locality Štrbské Pleso were provided by the Slovak Hydrometeorological Institute (Figures 1 and 2). Štrbské Pleso (1,354 $\mathrm{m}$ above sea level, central part of the Tatra Mountains) represents comparable and not very far locality. Monthly precipitation did not show a clear difference between the above two year groups. Definitely, eye larvae were not frequent in dry years 2000 and 2003. All the remaining summers and autumns in the period 1999 - 2005 had moderate or higher amount of rain. Concerning the temperatures, it is apparent that the most important month is August when eye larvae used to appear for the first time in the year in both mountain regions. In the years 1999, 2004 and 2005, Augusts were colder than in $2000-2004$. We might speculate that a combination of low temperatures with the rather wet conditions represent one of impulsions for the sudden appearance of the parasitic larvae of $R$. orbitalis, besides the normal free-living $\mathrm{L}_{3}$ larvae and probable preceding the appearance of "dauer" larvae that arrest their development during the winter seasons (Schulte, 1989). However, there is not clear why eye larvae were not found in autumn months of 2001 and 2002 when the temperature was also low and rainfall high.

Much more hypotheses could be stated about the impulses

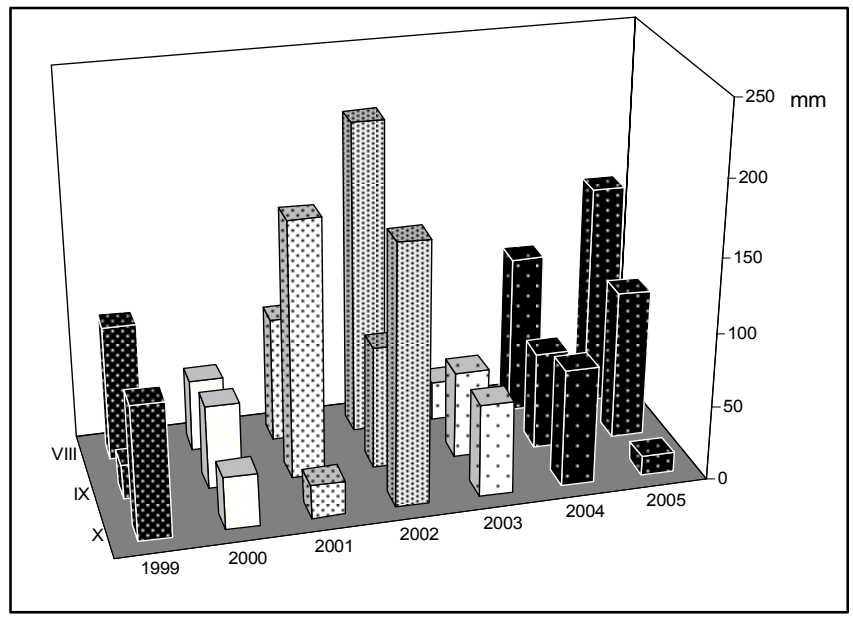

Fig. 1. Month rainfall values in August, September and October in years with (black columns) and without (white columns) occurrence of eye larvae in rodents

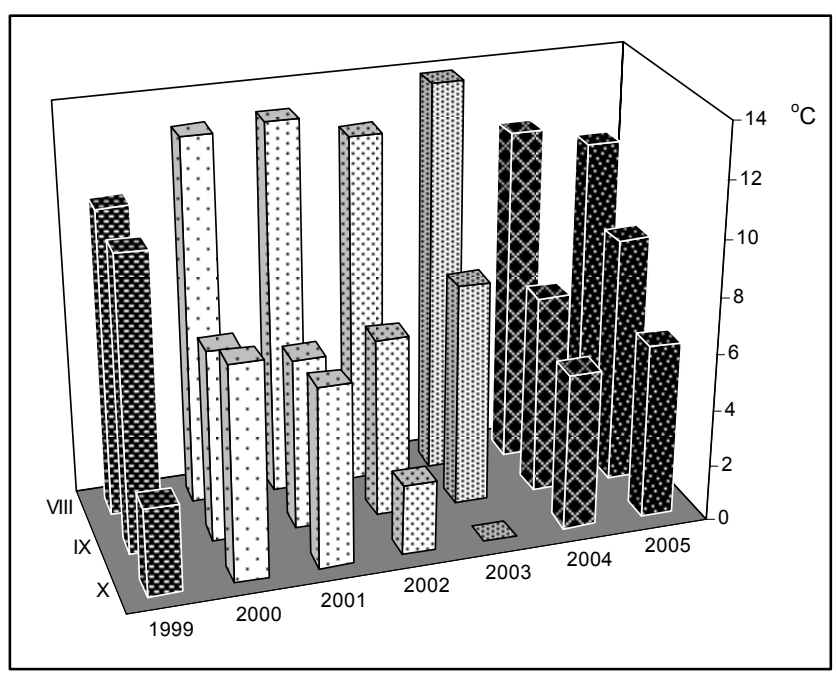

Fig. 2. Month temperature values in August, September and October in years with (black columns) and without (white columns) occurrence of eye larvae in rodents

for $R$. orbitalis eye larvae appearance. According to Schulte (1989) and Hugot and Quentin (2000), infective larvae find a protected environment inside rodent eyes which also provide a richer food of eye secretions comparing with nest substrate. This allows them to store lipid droplets and to grow somewhat, to survive condition of food deprivation and to develop rapidly into adults. In addition, infected rodents can act as agent of dispersal in situations when conditions for the non-parasitic development of nematodes impair. Therefore, we conclude that infective larvae might appear in case of over-breeding of the nematodes in a rodent nest after a favourable spring season and in years of decreased abundance of rodents when a number of temporary abandoned nests could appear. 
In conclusion, an acceptable hypothesis could be formulated in accord to Schulte (1989) that an appearance of parasitic larvae in the life cycle of bacteriophagous $R$. orbitalis could represent a strategy for surviving periods of resource scarcity, in particular those with a scarce bacterial food. However, this nematode species possesses quite rich inventory for species preservation, using also a developmenttally arrested dispersal stage called the "dauer" larva, broadly known in nematodes. Thus $R$. orbitalis offers an unusual opportunity to combine ecological and experimental research and elucidate in detail its intimate behavioural and physiological peculiarities.

\section{Acknowledgements}

This study was supported by the projects of Slovak Grant Agency VEGA Nos 2/4177/04, 1/7197/20 and 1/001703. We thank to the Slovak Hydrometeorological Institute for providing us with the month data of temperature and rainfall in years $1999-2005$. We would also like to thank all who helped us with the research of small ground mammals, namely to P. Miklós, D. Žiak and L. Kocian and two reviewers for valuable comments.

\section{References}

BARUŠ, V., HRABĚ, V. (1991): Larvae of Rhabditis orbitalis Sudhaus et Schulte, 1986 in the mountain rodents in Czech and Slovak Federative Rebublic. Helminthologia, 28: $93-97$

Casanova, J. C., Arrizabalaga, A., Špakulová, M., MORAND, S. (1996): The first record of Rhabditis (Pelodera) orbitalis (Nematoda: Rhabditidae), a larval parasite in the eyes of the rodent Chionomys nivalis on the Iberian Peninsula. Helminthologia, 33: 227 - 229

Cross, J. H., SAntana, F. J. (1974): Pelodera strongyloides (Schneider) in the eye orbits of Taiwan rodents. Chinese J. Microbiol., 7: $137-138$

Hugot, J. P., Quentin, J. C. (2000): Nemacycle: a coding system for representation of nematode life-cycles. Rev. Res. Parasitol., 60: $57-67$

ITO, M., ITAGAKI, T. (2003): Survey on wild rodents for endoparasites in Iwate Prefecture, Japan. J. Vet. Med. Sic., 65: $1151-1153$

KOCIANOVÁ, M., ŽIAK, D., KocIAN, L. (2002): Characteristics of individual territories of Tatra snow vole (Chionomys nivalis mirhanreini, Schaefer, 1935) in the West
Tatras - Roháče Mts. Výskum a ochrana cicavcov na Slovensku, 5: $121-130$

LuQue-Larena, J. J., LóPez, P., Gosálbez, J. (2002): Microhabitat used by the snow vole Chionomys nivalis in alpine environments reflects rock-dwelling preferences. Can. J. Zool., 80: $36-41$

MARTínKOVÁ, N., DuDICH A. (2003): The fragmented distribution of Microtus tatricus and its evolutionary implications. Folia Zool. 52: $11-22$

Prokopič, J., BARUŠ, V., HodKOVÁ, Z. (1974): Preliminary report on the incidence of larvae of the family Rhabditidae (Nematoda) in the eyes of rodents. Folia Parasitol., 21: $189-192$

Sainsbury, A. W., Bright, P. W., Morris, P. A., Harris, E. A. (1996): Ocular disease associated with Rhabditis orbitalis nematodes in a common dormouse (Muscardinus avellanarius). Vet. Rec., 24: $192-193$

SCHUlTE F. (1989). Life history of Rhabditis (Pelodera) orbitalis, a larval parasite in the eye of arvicolid and murid rodents. Proc. Helminthol. Soc. Wash., 56: $1-7$

Schulte, F., Poinar, G. O. (1991): On the geographical distribution and parasitism of Rhabditis (Pelodera) orbitalis (Nematoda: Rhabditidae). Proc. Helmintol. Soc. Wash., 58: $82-84$

Sudhaus, W., Asakawa, M. (1991): First record of the larval parasitic nematode Rhabditis orbitalis from Japanese wood mice (Apodemus spp.). J. Helminthol., 65: 232 - 233 Sudhaus, W., Schulte, F., Hominick, W. M. (1987): A further sibling species of Rhabditis (Pelodera) strongyloides (Nematoda): Rhabditis (P.) cutanea n. sp. from the skin of wood mice (Apodemus sylvaticus). Revue Nématol., 10: $319-326$

TENORA, F., BARUŠ, V. (1991): Helminths of Arvicola terrestris in Czechoslovakia and survey of helminthofauna of Arvicola spp. I. Helminths of A. terrestris and A. sappidus. Acta Univ. Agric. (Brno), 39: 233 - 241

Yagi, K., ItAyama, H., OKu, Y., SuZuKi, H. (1983): Helminth fauna of the field mouse, Apodemus speciosus, from Tokara islands, Japan. Jap. J. Parasit., 32: 42

Yensen, E., BAIRD, C.R., SHERMAN, P. W. (1996): Lager ectoparasites of the Idaho ground squirrel (Spermophilus brunneus). Great Basin Nat., 56: 237 - 246

ŽIAK, D., KOCIANOVÁ-ADAMCOVÁ, M., KOCIAN, L', MARTíNKOVÁ, N. (2004): High diversity of small terrestrial mammals in subalpine area of West Tatras. Výskum a ochrana cicavcov na Slovensku, 4: 45 - 57 